University of Michigan Law School

University of Michigan Law School Scholarship Repository

Law \& Economics Working Papers

8-31-2018

\title{
The International Provisions of the TCJA: Six Results after Six Months
}

Reuven S. Avi-Yonah

University of Michigan Law School, aviyonah@umich.edu

Follow this and additional works at: https://repository.law.umich.edu/law_econ_current

Part of the Law and Economics Commons, Taxation-Transnational Commons, and the Tax Law Commons

Working Paper Citation

Avi-Yonah, Reuven S., "The International Provisions of the TCJA: Six Results after Six Months" (2018). Law \& Economics Working Papers. 158.

https://repository.law.umich.edu/law_econ_current/158

This Article is brought to you for free and open access by University of Michigan Law School Scholarship Repository. It has been accepted for inclusion in Law \& Economics Working Papers by an authorized administrator of University of Michigan Law School Scholarship Repository. For more information, please contact mlaw.repository@umich.edu. 


\title{
THE INTERNATIONAL PROVISIONS OF THE TCJA: SIX RESULTS AFTER SIX MONTHS
}

\author{
Reuven S. Avi-Yonah ${ }^{1}$
}

\begin{abstract}
Over six months have passed since the enactment of the TCJA, so it is now possible to reach some preliminary conclusions on its impact. The main ones are:
\end{abstract}

1. The transition tax plus anticipated GILTI tax minus territoriality have resulted in higher GAAP effective tax rates for 2017. In some cases they approach $35 \%$ for large multinationals with a lot of offshore income. For the first six months of 2018, however, overall corporate tax revenues are sharply down because of the $21 \%$ rate plus expensing. This is the exact reverse of the situation before TCJA in which MNEs showed very low effective tax rates on the financials but overall corporate revenue was remarkably robust.

2. As expected, the transition tax has resulted in a significant repatriation of offshore earnings that were primarily invested in stock buybacks.

3. The main outcome of TCJA in in the international arena is not territoriality (i.e., participation exemption) with a minimum tax, but rather a worldwide tax regime with no deferral, but with a lower rate for foreign income. That is because for most of the large US MNEs the amount of offshore income that can avoid GILTI and therefore be eligible for zero tax under territoriality is very small.

4. FDII is a failure, it is too risky to move intangibles into the US because it may be a Hotel California situation if the law is changed. This may be why there is no WTO challenge.

5. BEAT is a success, although the revenue estimate is too high, because it may be easy to avoid by recharacterizing royalties as cost of goods sold under 263A. But this could be subject to the BEAT anti-abuse rule.

6. The FTC, which was supposed to become less important because of territoriality, is more important because 960 is the new 902, with five baskets instead of two (general, passive, GILTI, branch, treaties). This has created significant complexity and much work for tax lawyers.

\footnotetext{
${ }^{1}$ Irwin I. Cohn Professor of Law and Director, International Tax LLM, the University of Michigan. I would like to thank Shay Moyal (SJD candidate, University of Michigan) for his help with this article.
} 
Over six months have passed since the enactment of the Tax Cuts and Jobs Act (TCJA) on December 22, 2017, so it is now possible to begin to evaluate its real world impact. The following conclusions regarding the international provisions are necessarily very preliminary, and it will be a long time before the practical ramifications of TCJA can truly be assessed, even if it is not modified or repealed.

\section{a. Increased ETRs.}

One remarkable fact that has already emerged is that many US-based multinationals have reported higher GAAP effective tax rates (ETRs) for 2017 compared to previous tax years. ${ }^{2}$ This outcome is the result of (a) the one-time transition tax $(15.5 \%$ on liquid offshore assets plus $8 \%$ on illiquid assets), plus (b) the anticipated GILTI tax, which must be recorded as a deferred tax item with no "permanent reinvestment" option, minus (c) territoriality, which eliminates any deferred tax for MNEs that could not declare all of their offshore earnings as "permanently reinvested" (e.g., Apple). In some cases, ETRs for 2017 approach $35 \%$ for large multinationals with a lot of offshore income. ${ }^{3}$

On the other hand, for the first six months of 2018, overall US corporate tax revenues are sharply down. ${ }^{4}$ The revenue impact is presumably because of the reduction of the corporate rate from $35 \%$ to $21 \%$, plus expensing. This sharp reduction occurs at a time when corporate profits are soaring and the deficit is ballooning, and is likely to lead to calls to

\footnotetext{
${ }^{2}$ https://itep.org/15-companies-report-tax-savings-of-6-2-billion-in-first-threemonths-of-2018. This is in comparison with 2017 rates, which were inflated by the one time transition tax. See also Fortune, Apple Leads These Companies With Massive Overseas Cash Repatriation Tax Bills (January 18, 2018).

${ }^{3}$ ITEP, supra.

${ }^{4}$ ITEP, supra. Perhaps because of the rate reduction plus expensing, there have been few post-TCJA inversions, despite the move to worldwide taxation discussed below. One exception is Ohio-based Dana Incorporated, which announced on March 9, 2018, that it was planning on inverting to the United Kingdom. See: Jim Tankersley, How the Trump Tax Cut Is Helping to Push the Federal Deficit to \$1 Trillion The New York Times (2018), https://www.nytimes.com/2018/07/25/business/trump-corporate-tax-cutdeficit.html (last visited Aug 30, 2018). In The Wall Street Journal, the company's CFO said that "even with the new tax legislation, there is a benefit for us." The company expects that this move will reduce its tax liability by around $\$ 600$ million over several years. See: Chester Dawson \& Theo Francis, Despite U.S. Tax Overhaul, Ohio-Based Dana Considers a Move Abroad The Wall Street Journal (2018), https://www.wsj.com/articles/dana-to-take-over-gkns-automotive-drivelinebusiness-1520614366 (last visited Aug 30, 2018).
} 
increase the corporate tax rate if the Democrats take over Congress and the White House in 2018/2020.

Interestingly, the combination of increased ETRs and reduced corporate revenues is the exact reverse of the situation before TCJA, in which MNEs showed very low effective tax rates on the financials, but overall corporate revenue was remarkably robust (at least in OECD, but also in the US if we ignore the corporate tax shelter wave before 2006 and the dip due to the Great Recession).

\section{b. Repatriation.}

As expected, the transition tax has resulted in a significant repatriation of offshore earnings. As of a Senate Finance Committee hearing on April 24, 2018, the TCJA has resulted in over $\$ 300$ billion in repatriations. ${ }^{5}$ Also as expected, of this amount, $\$ 260$ billion has been spent on stock buybacks. The contrast between this amount and the amount spent on employee bonuses ( $\$ 6.5$ billion) has led to sharp critiques of the TCJA's international provisions, and may bolster the political case for a future rate increase.

\section{c. A Worldwide Regime.}

When tax reform was discussed in the years leading up to 2017, it was generally assumed that it will include "territoriality" (i.e., a participation exemption for non-Subpart F income of CFCs), plus some kind of minimum tax on offshore income. This was a consensus view of both the Obama and Trump Administrations and the GOP majority in Congress. ${ }^{6}$ Critical voices advocated instead a worldwide regime with lower tax rates. ${ }^{7}$

Somewhat surprisingly (at least to this writer), the main outcome of TCJA in the international arena is not territoriality (i.e., participation exemption) with a minimum tax, but rather a worldwide tax regime with no deferral, but with a lower rate for foreign income. That is because for most of the large US MNEs the amount of offshore income that can avoid GILTI and therefore be eligible for zero tax under territoriality is very

${ }^{5}$ Early Impressions of the New Tax Law, https://www.finance.senate.gov/hearings (April 24, 2018).

${ }^{6}$ On the similarity between the Obama and GOP proposals see Avi-Yonah, Proposals for International Tax Reform: Is There A Middle Road? 153 Tax Notes 1169 (Nov. 28, 2016).

${ }^{7}$ Avi-Yonah, Proposals for International Tax Reform: Problem or Opportunity?, Challenge, DOI: 10.1080/05775132.2016.1272968 (2017). 
small. Large US MNEs do not have enough tangible investments offshore to benefit meaningfully from an exemption based on a $10 \%$ return on their basis in tangible assets.

This could, of course, change if the MNEs respond by moving tangible assets offshore. ${ }^{8}$ But in that case, pressure will increase to repeal the GILTI exemption, because it will be perceived as leading to loss of US jobs.

The enactment of a world-wide regime is a goal that has eluded Democrats since the Kennedy administration. It is deeply ironic that this goal has been achieved by a GOP controlled Congress and White House. Democrats need only increase the GILTI rate to $21 \%$, and full parity between onshore and offshore income will be achieved at last.

\section{d. FDII.}

FDII, which was designed to attract intangibles into the US, is so far a failure. There is no discernible increase in inbound FDI. ${ }^{9}$ The reason may be that it is too risky to move intangibles into the US, because it may be a Hotel California situation ("you can check in, but you cannot check out") if the law is changed, and then the intangibles are trapped in the US because of the enhanced IRC 367 and 482.

Another possible reason why the FDII is a failure is the assumption that the WTO will strike it down if it is challenged, like it did its predecessors. ${ }^{10}$ This creates uncertainty and deters investment in

\footnotetext{
8 The Congressional Budget Office has stated that "The GILTI and FDII provisions affect corporations' decisions about where to locate tangible assets. By locating more tangible assets abroad, a corporation is able to reduce the amount of foreign income that is categorized as GILTI. Similarly, by locating fewer tangible assets in the United States, a corporation can increase the amount of U.S. income that can be deducted as FDII. Together, the provisions may increase corporations' incentive to locate tangible assets abroad." See: The Congressional Budget Office, (2018), https://www.cbo.gov/publication/53651 (last visited Aug 30, 2018).

${ }^{9}$ See: Foreign Direct Investment in the United States, Preliminary 1st Quarter 2018 (2018), https://ofii.org/report/foreign-direct-investment-in-the-unitedstates-preliminary-1st-quarter-2018 (last visited Aug 30, 2018).

${ }^{10}$ See Avi-Yonah, Does the United States Still Care About Complying with its WTO Obligations, Columbia J. Tax Law Tax Matters 12 (2018); Avi-Yonah, Reuven S. and Vallespinos, Martin, The Elephant Always Forgets: US Tax Reform and the WTO (January 28, 2018). U of Michigan Law \& Econ Research Paper No. 18-006; U of Michigan Public Law Research Paper No. 596. Available at
} 
reliance on the FDII. There has been no challenge so far, but that may be precisely because the FDII is a failure, so our trading partners do not care.

\section{e. BEAT.}

BEAT is a success, at least if one listens to the endless complaints about it from practitioners, which indicates it has real teeth. ${ }^{11}$ In particular, it applies not only to US subsidiaries of foreign multinationals, but also to CFCs, and not just to interest and royalties, but also to other types of deductible payments, such as cost sharing payments and global dealing payments. The interaction with GILTI is important, as are the interactions with the laws of other countries (leading to potential double taxation, since there is no FTC to credit against BEAT liability).

One problem area from the perspective of protecting the US tax base is that it may be possible to avoid BEAT by recharacterizing royalties (subject to BEAT) as cost of goods sold (not subject to BEAT) under IRC section 263A. But such a maneuver could be subject to the BEAT antiabuse rule. ${ }^{12}$

BEAT raises interesting issues under treaties. ${ }^{13}$ While the savings clause protects it from being a treaty override for the purposes of most treaty articles, the savings clause does not apply to the non-discrimination article (24), and it has been argued that BEAT is discriminatory. ${ }^{14}$ In that case, it is a treaty override, but it also means that existing pending

SSRN: https://ssrn.com/abstract=3113059 or http://dx.doi.org/10.2139/ssrn.31 13059

${ }^{11}$ See e.g. Martin A. Sullivan, Economic Analysis: Can Marked-Up Services Skip the BEAT? Tax Notes (2018), https://www.taxnotes.com/tax-reform/economicanalysis-can-marked-services-skip-beat (last visited Aug 30, 2018); Heather Ripley, "If You Can't Stand The BEAT, You're Still Stuck In The Kitchen," Alston \& Bird (2018), https://www.alston.com/en/insights/publications/2018/03/cantstand-the-beat (last visited Aug 30, 2018).

1226 CFR Section 59A(i).

${ }^{13}$ Avi-Yonah, Reuven S., Beat It: Tax Reform and Tax Treaties (January 4, 2018). U of Michigan Public Law Research Paper No. 587; U of Michigan Law \& Econ Research Paper No. 18-003. Available at

SSRN: https://ssrn.com/abstract=3096879 or http://dx.doi.org/10.2139/ssrn.3096 879

${ }^{14}$ Peter Barnes \& David Rosenbloom, US plays Lone Ranger on international tax to its detriment, The Hill (Jan. 19, 2018), http://thehill.com/opinion/finance/369719us-plays-lone-ranger-on-international-tax-to-its-detriment; Bret Wells, Get With the BEAT, Tax Notes, Feb. 19, 2018. 
treaties cannot be ratified lest they override the BEAT. ${ }^{15}$ In my opinion, however, the application of the BEAT to US-based MNEs means that it is not a violation of article 24 .

\section{f. FTC.}

It was anticipated that tax reform would render the foreign tax credit (FTC) much less important because of the adoption of territoriality and the repeal of IRC section 902. Instead, because TCJA resulted in practice in a world-wide regime, the FTC is more important. IRC section 960 is the new 902, with five baskets instead of two (general, passive, GILTI, branch, treaties). Horrible complexities arise in the interaction with the various loss limitation rules, and the predictable result is endless work for tax lawyers.

The author started practicing tax law in the summer of 1987, when the 1986 tax act was brand new and every young associate could know as much about some of its innovative provisions (e.g., the branch profit tax) as the most senior tax partner. We are now in the same position again, and it is a wonderful time to be practicing tax law. There are many complexities to be unraveled, and more legislation may be forthcoming, but for now let us all take a deep breath and enjoy the ride.

${ }^{15}$ On the override issue compare Rosenbloom, H. David and Shaheen, Fadi, The BEAT and the Treaties (August 1,2018). Available at SSRN: https://ssrn.com/abstract=3229532 with Wells, Bret and Avi-Yonah, Reuven S., The Beat and Treaty Overrides: A Brief Response to Rosenbloom and Shaheen (August 16, 2018). U of Houston Law Center Research Paper; U of Michigan Law \& Econ Research Paper No. 18-019; U of Michigan Public Law Research Paper No. 617. Available at SSRN: https://ssrn.com/abstract=3232974. 